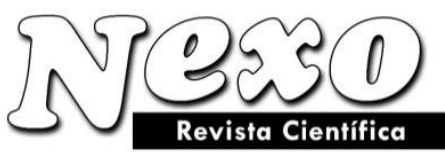

Vol. 34, No. 02, pp. 973-992/Junio 2021

\title{
Assessment of organic matter temporal dynamics in the klyazma basin using remote sensing and qgis trends.earth
}

\section{Evaluación de la dinámica temporal de la materia orgánica en la cuenca de klyazma utilizando monitoreo remoto y qgis trends.earth}

\author{
Tatiana A. Trifonova ${ }^{1}$, Natalia V. Mishchenko ${ }^{2, *}$, Pavel S. Shutov ${ }^{2}$ \\ ${ }^{1}$ Department of Soil Science, Lomonosov Moscow State University, Moscow, Russian Federation \\ ${ }^{2}$ Institute of Biology and Ecology, Vladimir State University, Vladimir, Russian Federation \\ *natmich3@mail.ru
}

(recibido/received: 15-febrero-2021; aceptado/accepted: 05-abril-2021)

\begin{abstract}
The article addresses the dynamics of biological processes in various landscapes within a holistic natural geosystem - a catchment area. The Klyazma river (the fourth order tributary to the Volga) was selected as the object of study. The natural complex of the Klyazma river basin is a combination of different landscapes, each marked by a diverse composition of geomorphological and soil-vegetation structures. The study is based on remote sensing data and the Trends.Earth Land Degradation Monitoring Project (Land Cover Dataset, European Space Agency 2015, $300 \mathrm{~m}$ spatial resolution) implemented using the open-source Quantum GIS 2.18. Four landscape provinces and eight site were identified in the studied catchment area according to the geomorphological structure and the soil and vegetation cover. The ecosystem parameters Gross Primary Productivity, Net Primary Productivity, and Ecosystem Respiration were measured in the identified sites. In different landscapes the biological processes, characterizing the organic matter dynamics in the form of plant production and organic matter accumulation, differ in both rate and intensity, and variously respond to the changes in climate parameters and land use. The river basin, as a holistic ecosystem, showed sufficient stability of the dynamic processes. This suggests that holistic natural ecosystems, such as catchment areas, have internal compensatory mechanisms that maintain the development stability over long period of time, while irrational land use remains the main damaging factor.
\end{abstract}

Keywords: Productivity dynamics; Biological process; River basin; Biological property; Irrational using; Remote Sensing.

\section{RESUMEN}

El artículo está dedicado al estudio de la dinámica de los procesos biológicos en los paisajes en los limites de la zona de captación. Se eligió como zona modelo la cuenca del río Klyazma (que esta entrando con un afluente de cuarto orden a la cuenca del Volga), que es una combinación bastante compleja de diferentes paisajes. El estudio se basó en datos de teledetección. Se eligieron como parámetros los indicadores de fito-productividad y de carbono del suelo. Se estableció que en los distintos paisajes los procesos 
biológicos difieren tanto en velocidad como en intensidad y responden de forma ambigua a los cambios en los parámetros climáticos y al cambio en el uso del suelo. Sin embargo, en general, la cuenca hidrográfica, como ecosistema único, mostró suficiente estabilidad en los procesos dinámicos. Esto indica que los ecosistemas naturales holísticos tienen internas propiedades compensatorias.

Palabras claves: Dinámica de productividad; Procesos biológicos; Cuenca hidrográfica; Propiedades biológicas; Uso irracional; Teledetección.

\section{RESUMEN}

El artículo está dedicado al estudio de la dinámica de los procesos biológicos en los paisajes en los limites de la zona de captación. Se eligió como zona modelo la cuenca del río Klyazma (que esta entrando con un afluente de cuarto orden a la cuenca del Volga), que es una combinación bastante compleja de diferentes paisajes. El estudio se basó en datos de teledetección. Se eligieron como parámetros los indicadores de fito-productividad y de carbono del suelo. Se estableció que en los distintos paisajes los procesos biológicos difieren tanto en velocidad como en intensidad y responden de forma ambigua a los cambios en los parámetros climáticos y al cambio en el uso del suelo. Sin embargo, en general, la cuenca hidrográfica, como ecosistema único, mostró suficiente estabilidad en los procesos dinámicos. Esto indica que los ecosistemas naturales holísticos tienen internas propiedades compensatorias.

Palabras claves: Dinámica (dinámica de la fito-productividad); Procesos biológicos; Cuenca hidrográfica; Propiedades biológicas; Uso irracional; Teledetección.

\section{INTRODUCTION}

Practical implications of environmental research on a planetary scale have become more substantial due to the development of space-borne remote sensing, which allows examining the surface conditions of vast areas with high spatial and temporal resolution. When studying carbon assimilation by forest ecosystems on a large territory, remote sensing data make it possible to estimate such an important indicator as the rate of metabolic processes involving organic carbon (Ovington, 1962; Goetz, Prince, 1999; Salunkhe et al., 2018).

Remote sensing data are also useful for assessing components of the ecosystem services (biological productivity, soil formation, absorption and fixation of nutrients in various media) (Truchy et al., 2015; Wang et al., 2015).

Recently, there have appeared ecosystem productivity evaluation models that use remote sensing data and operate indicative measurable indices, such as Normalized Difference Vegetation Index (NDVI), Enhanced Vegetation Index (EVI), Leaf Area Index (LAI), and Fraction of Photosynthetically Active Radiation (FPAR) (Hashimoto et al., 2012; Chen et al., 2019). However, despite this interest in remote sensing applications, there is still a need for commonly accepted approaches to assessing, analyzing, and forecasting the biological productivity of ecosystems (Robinson et al., 2018; Li et al., 2019; Varghese, \& Behera, 2019).

The open-source global data on gross primary productivity (GPP) collected by the MODIS sensor are increasingly used to examine the carbon cycle associated with terrestrial ecosystems (Turner et al., 2006; $\mathrm{Wu}$ et al., 2010). Researchers are developing approaches to determining the carbon balance based on remote data, and investigating the equilibrium of inputs and losses of soil carbon and the accumulation of soil carbon (Guo \& Gifford, 2002; Van der Werf et al., 2009; Deng et al., 2014; Krasilnikov, 2015; Deng et al., 2016). Global data on the soil cover can help quantify various types of lands in order to find optimal paths of land use, predict the availability of land resources and rationalize nature management (Dong et 
al., 2019; Meyer \& Riechert, 2019). Some works have addressed the relationship between the change in land use and the spatiotemporal dynamics of carbon flows (Novick et al., 2015).

Environmental research addresses ecosystems of various hierarchical levels. One of the ecosystem types is the river basin. This study applies the catchment area approach because river basins have fairly clear natural boundaries, i.e. watersheds. The flows of the surface and subsoil water runoffs and the migration of dissolved substances and solids are integrally confined to the watersheds. Interacting endogenous and exogenous factors drive the formation and functioning of catchment areas, and, geographically, any river basin develops within the boundaries shaped by a number of climatic factors (Trifonova, 2005, 2008). Proceeding from these positions, a river basin is regarded as a natural ecosystem (Fitoka et al., 2020).

The most interesting characteristics of the vegetation cover are usually the indicators of its productivity. The vegetation cover productivity has been factored into many studies of the natural resource and bioresource potentials of landscapes (Odum, 1983; Bazilevich et al., 1986; Isachenko, 1991; Qader et al., 2015; Tian, 2015; Dedeoglu et al., 2019; Prince, 2019; Sun et al., 2019). Since the solutions to many environmental management problems rely on information on the state and the use of vegetation and topsoil on the land surface, it is necessary to have relevant and objective information on soil and vegetation, in particular, the content of organic matter, the physical and mechanical properties, the bulk chemical composition of soil, the type of land use in that particular territory, and the composition of plant formations. (Trifonova \& Mishchenko, 2018).

Gross Primary Productivity (GPP), Net Primary Productivity (NPP), and Ecosystem Respiration (RE) are the key indicators that determine the carbon balance of ecosystems (Valentini et al., 2000; Kudeyarov et al., 2007). GPP gives a measure of the total organic matter production by plants per unit area over a certain period of time. In the set of vegetation indices, LAI appears to correlate with GPP best of all.

However, at present it is difficult to name any uniform method for studying fundamental spatial geosystems, especially from the perspective of GIS, carbon content modeling, and assessment of the land cover and the productive biomass based on space-born remote sensing.

The purpose of study was to assess the state and the functioning dynamics of organic matter in the soil and vegetation cover of the Klyazma River basin over a 15-year period using remote sensing data and QGIS Trends.Earth.

The object of study was the basin of the Klyazma River located in the center of the East European Plain. It is a $686 \mathrm{~km}$ long left tributary to the Oka with a west-east trending catchment area of 42,500 sq km (Fig. 1). In this work, the Klyazma River basin was considered as a single ecosystem albeit marked by certain internal diversity (Trifonova, 2018).

The subject matter of study was the soil and vegetation cover that determines the landscape diversity of the Klyazma River basin. On its territory there are different natural areas with varying degrees of anthropogenic impact. The state of vegetation was assessed generally in the catchment area and individually on eight sites located in the identified landscape provinces (Figures 1 and 2). The eight sites were the following:

I. The Klin-Dmitrov Province was represented by two sites corresponding to the natural areas that differ significantly by the soil and vegetation cover.

Site 1. Geomorphologically, the greater part of the Klin-Dmitrov Ridge is a poorly broken morainic plain covered by low-hilly and hummock-and-hollow terminal moraines. Soddy cryptopodzols and mesopodzols prevail in the soil cover. Spruce and, patchily, broad-leaved species are abundant in the 
upland forest communities that cover approximately $30 \%$ of the site. About $45 \%$ of the land is ploughed up.

Site 2. In the Vladimir High Plain, the terrain is shaped by the alternation of ridges with very smooth, gentle slopes and large hollows with flat bottoms. Streams and rivers flow in some of the hollows. The soil cover is mainly a combination of gray wood soils on the hill tops and the upper slopes, and dark-gray wood soils on the lower slopes. The hill tops and the slopes are mostly ploughed up or fallowed. More than $60 \%$ of lands are cultivated. Meadows with a varying degree of wetting, sometimes to the point of bogginess, occupy the hollows.

II. The Meshchera Province has a uniform landscape, represented by one site.

Site 3. The Meshchera Site is a flat boggy alluvial Upper Pleistocene-Holocene plain in the Middle Klyazma woodland. Podzolic and sod-podzolic gley soils prevail in the interfluves; peaty-podzolic gley soils, on the slopes of elevations; and peaty bog soils, in the depressions. Alluvial slimy-humic-gley bog soils dominate along the Klyazma tributaries. The Middle Klyazma woodland is covered with forests by $85 \%$. Pine trees are abundant, occupying 75 to $90 \%$ of the woodland. The forest cover is unevenly interspersed by fields and meadows formed around villages gravitating to the banks of Klyazma.

III. The Volga-Klyazma Province had two sites.

Site 4. The Nerl-Klyazma Lowland is a flat and gently undulating, poorly broken morainic water-glacial plain of the Moscow glaciation. The Upper Pleistocene alluvial soils dominate the parent rock material. The soils are sod-podzolic loamy and sabulous on the elevated interfluves, peaty in the lowlands, and alluvial argillo-arenaceous within the river terraces and floodplains. The forest cover is unevenly preserved, occupying from 35 to $95 \%$ of the territory in different areas. The agricultural development is insignificant.

Site 5. The Lower Lukh Site is the most waterlogged area in the lower reaches of the Luh River, with swamps sprawling out. Under the conditions of surface water stagnation, the peat-gley soils with sandy sod-podzolic patches were formed, pointing to the ancient deltas of glacial water flows. There are evergreen coniferous forests with abundant spruce and pine species. Cereal-herbaceous phytocenoses dominate the flood meadows.

IV. The Oka-Tsna Province was represented by three sites due the diverse landscapes.

Site 6. The Oka-Tsna Wall is a high Dnieper morainic-glacial undulating wooded watershed, marked by widespread karst, deep-lying ground waters, and extremely underdeveloped hydrographic networks. Anthropogenic development of the landscape is insignificant. The soil cover consists of soddy cryptopodzols and mesopodzols. The uniform forest cover (pine and birch-pine stands rich in lichens and grasses) is only disturbed by rare plots of open agricultural land next to the villages.

Site 7. The Kovrov-Kasimov Plateau is a gently sloping well-drained Dnieper morainic-glacial plain. The karstic phenomena are well developed. The soils are soddy modal podzols, weakly gley soddy podzols, and gley soddy podzols. The site is unevenly covered (about 70\%, sometimes less than $30 \%$ ) with boreal forests such as pine woods, pine woods with some spruces, and less often spruce woods. The open spaces formed by cultivated areas are rather vast, although a significant part of these farmlands have been abandoned and turned into laylands.

Site 8. The Gorokhovets Spur is an intensely erosion-dissected, gently undulating Dnieper morainicglacial plain. The soils cover includes soddy modal podzols and washed-off truncated soddy podzols on the high interfluves, truncated soddy podzols on the slopes, and washed-off and alluvial soils at the 
footslopes and in the gullies and ravines. Forests occupy about $35 \%$ of the site and are confined to steep slopes and ravines. Flat tops of the watersheds are small and nearly all ploughed up.

Fig. 1 and fig. 2 show the sites on the map and their satellite images.
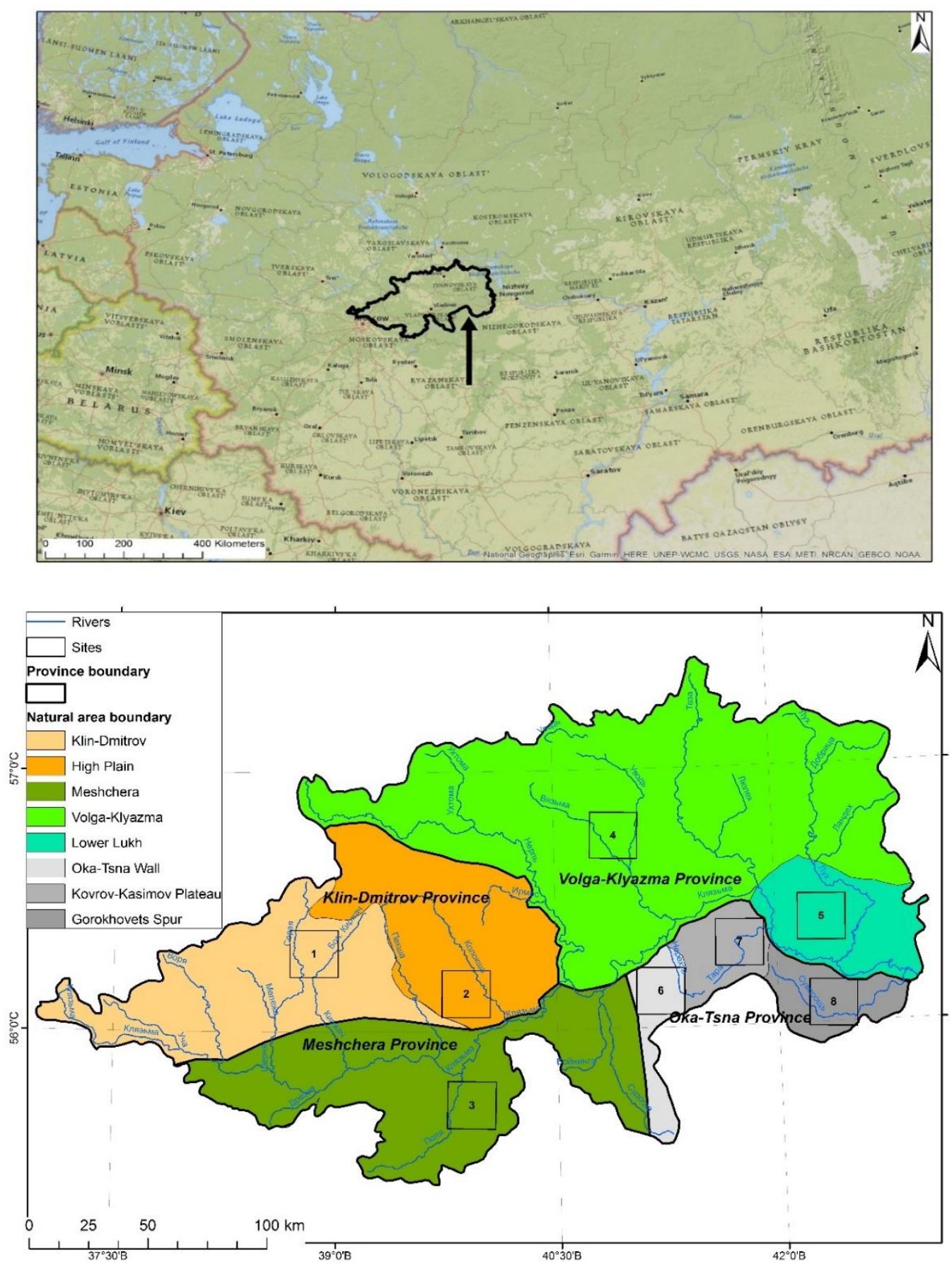

Figure 1. Sites in the identified landscape provinces: (a) the Klyazma River basin; (b) landscapes within the Klyazma River basin and the sites 


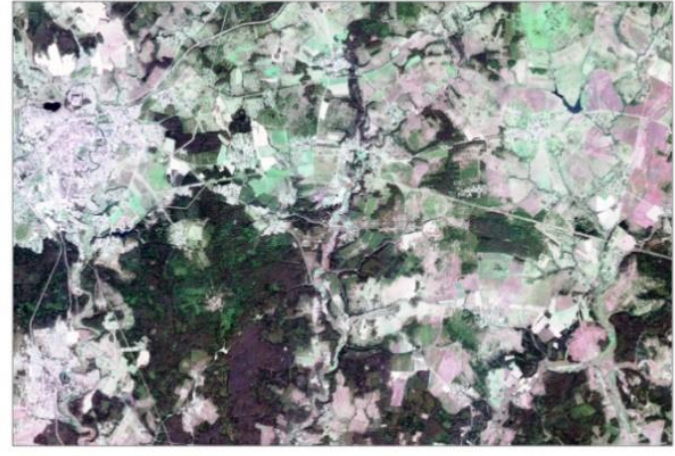

Site 1 - Klin-Dmitrov Ridge

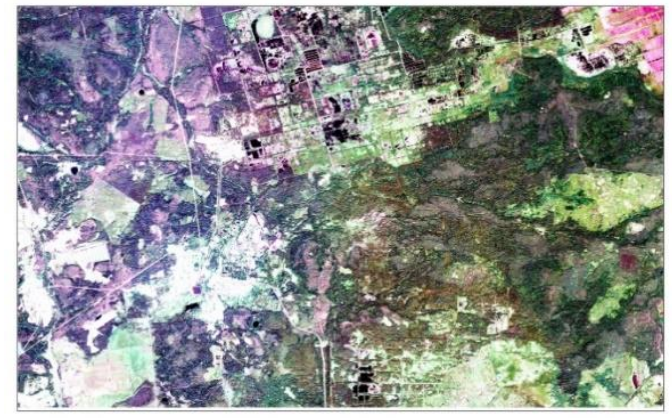

Site 3 - Meshchera Site

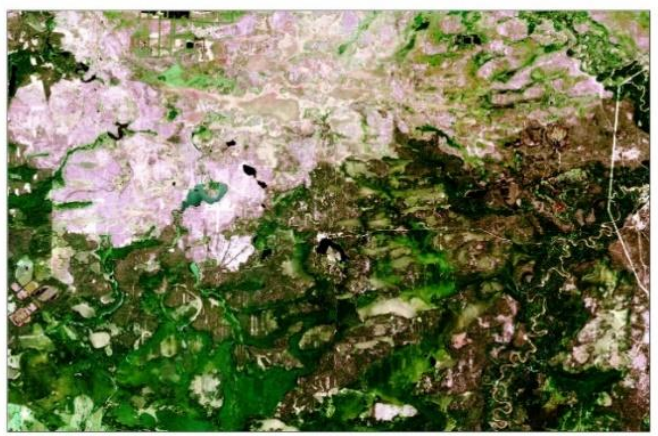

Site 5 - Lower Lukh Site

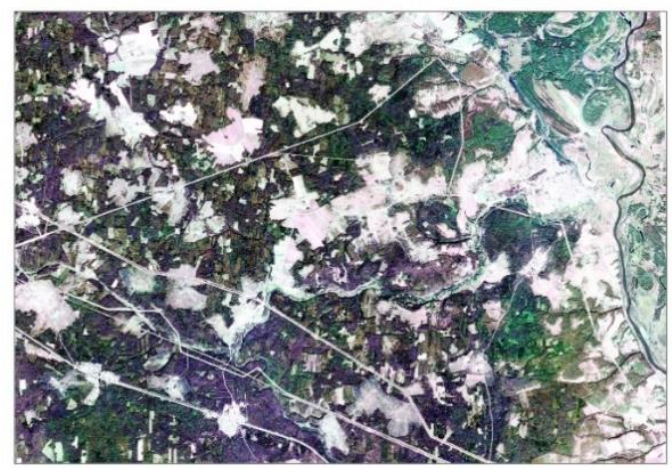

Site 7 - Kovrov-Kasimov Plateau

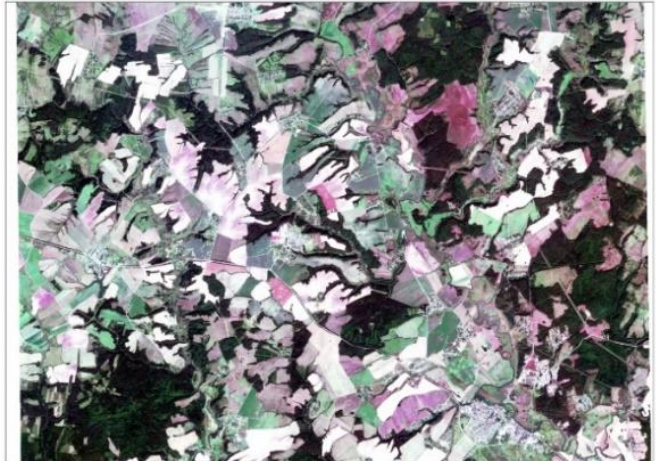

Site 2 - Vladimir High Plain

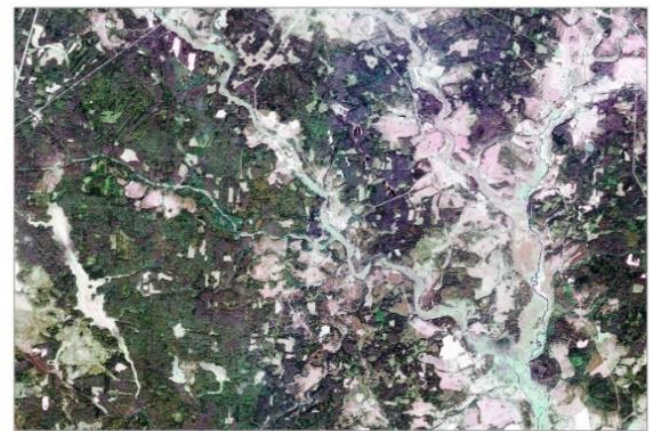

Site 4 - Nerl-Klyazma Lowland

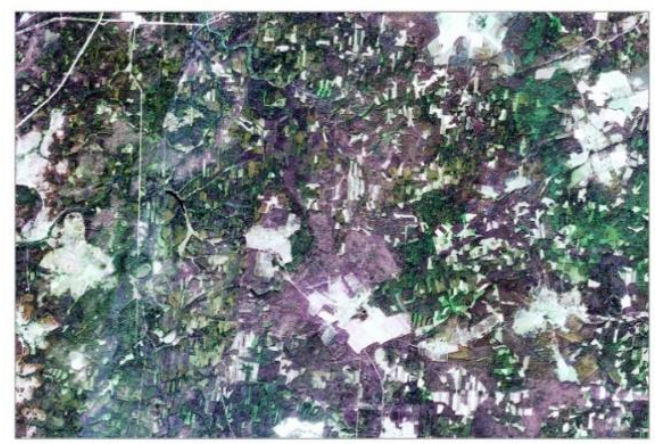

Site 6 - Oka-Tsna Wall

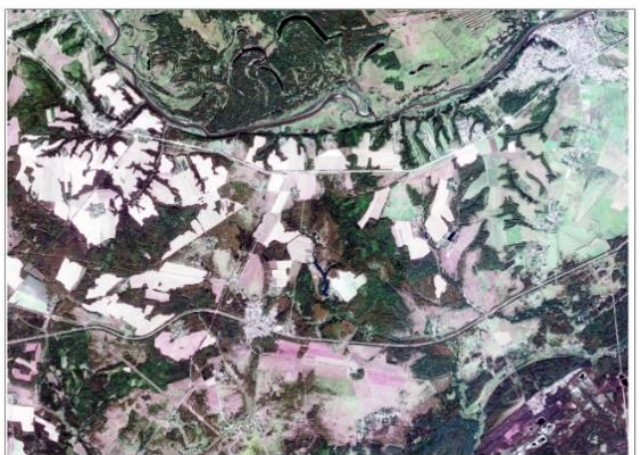

Site 8 - Gorokhovets Spur

Figure 2. Satellite images of the sites (Sentinel-II, Aug 2018): Site 1 - Klin-Dmitrov Ridge, Site 2 Vladimir High Plain, Site 3 - Meshchera Site, Site 4 - Nerl-Klyazma Lowland, Site 5 - Lower Lukh Site, Site 6 - Oka-Tsna Wall, Site 7 - Kovrov-Kasimov Plateau, Site 8 - Gorokhovets Spur. 


\section{MATERIALS AND METHODS}

The geoinformation analysis of remote sensing data and cartographic information on the soil and vegetation cover was performed applying the catchment area approach.

The river network vectorization and the boundary determination were carried out on the basis of the digital elevation model (DEM). The input data were the Shuttle Radar Topography Mission (SRTM) $90 \mathrm{~m}$ data. Having prepared the DEM, the river network and the catchment area boundaries were vectorized by automated geo-modeling methods in ESRI ArcGis10.4 using the Hydrology toolset (Ermolaev et al., 2014).

The land types were identified by HDF raster images made on the same four dates in 2001, 2005, 2009 and 2017 according to the MODIS open-source data of (Friedl \& Sulla-Menashe, 2015). For a more detailed analysis, we resorted to the Trends.Earth Land Degradation Monitoring Project (Land Cover Dataset, European Space Agency 2015, $300 \mathrm{~m}$ spatial resolution) implemented using the open-source Quantum GIS 2.18 (Fig. 2) (Trends. Earth, 2018).

The productivity indicators were calculated in carbon units based on the MODIS GPP/NPP data (Running et al., 2019). The resulting set of raster images in the HDF format was processed by the reclassification and statistics tools of the ArcGIS package. When calculating the carbon balance, we obtained the GPP, NPP and RE values (all in $\mathrm{gC} / \mathrm{m} 2$ ) for 2000-2015.

The soil organic carbon pool was determined by the UN FAO's data based on Trends.Earth and QGIS 2.18 (Trends. Earth, 2018). The data were generalized according to the Soil Grids global database of the International Soil Reference and Information Centre with a $250 \mathrm{~m}$ spatial resolution at a depth of 0 to 30 $\mathrm{cm}$ for 2001-2015 (SoilGrids, 2019). The dynamics of soil and vegetation cover for 2001-2015 was calculated in the whole Klyazma River basin and in each site using Trends.Earth and QGIS 2.18 (Trends. Earth, 2018).

The weather statistics was taken from weather website rp5.ru (Raspisaniye Pogody, 2020). The mathematical data processing was performed using Microsoft Excel and STATISTICA 10.

\section{RESULTS}

\subsection{Dynamics of Land Use in the River Basin}

According to the classification of the International Geosphere-Biosphere Program, the Klyazma River basin includes ten classes of land cover. As of 2017, almost $60 \%$ of the basin was covered by mixed forests, about $20 \%$ were occupied by grasses, shrubs and open woodlands, and about $14 \%$ were arable lands.

The conjoint quantitative and graphical analysis of data on the land use structure in the basin in 20012017 revealed the following changes in the area of different lands (Fig. 3):

1) the area of mixed forests that form the main vegetative cover of the basin increased by $9.0 \%$;

2) the area of shrub vegetation and open woodlands decreased by 2.3 and $2.2 \%$, respectively, primarily as a result of succession and their subsequent transition to forests,

3) the area of natural meadows, ploughlands/pastures, and broad-leaved forests decreased by 2.1, 1.0 and $0.1 \%$, respectively,

4) there was a $1 \%$ increase in the area of urbanized territories; water surfaces and swamps also grew slightly. 


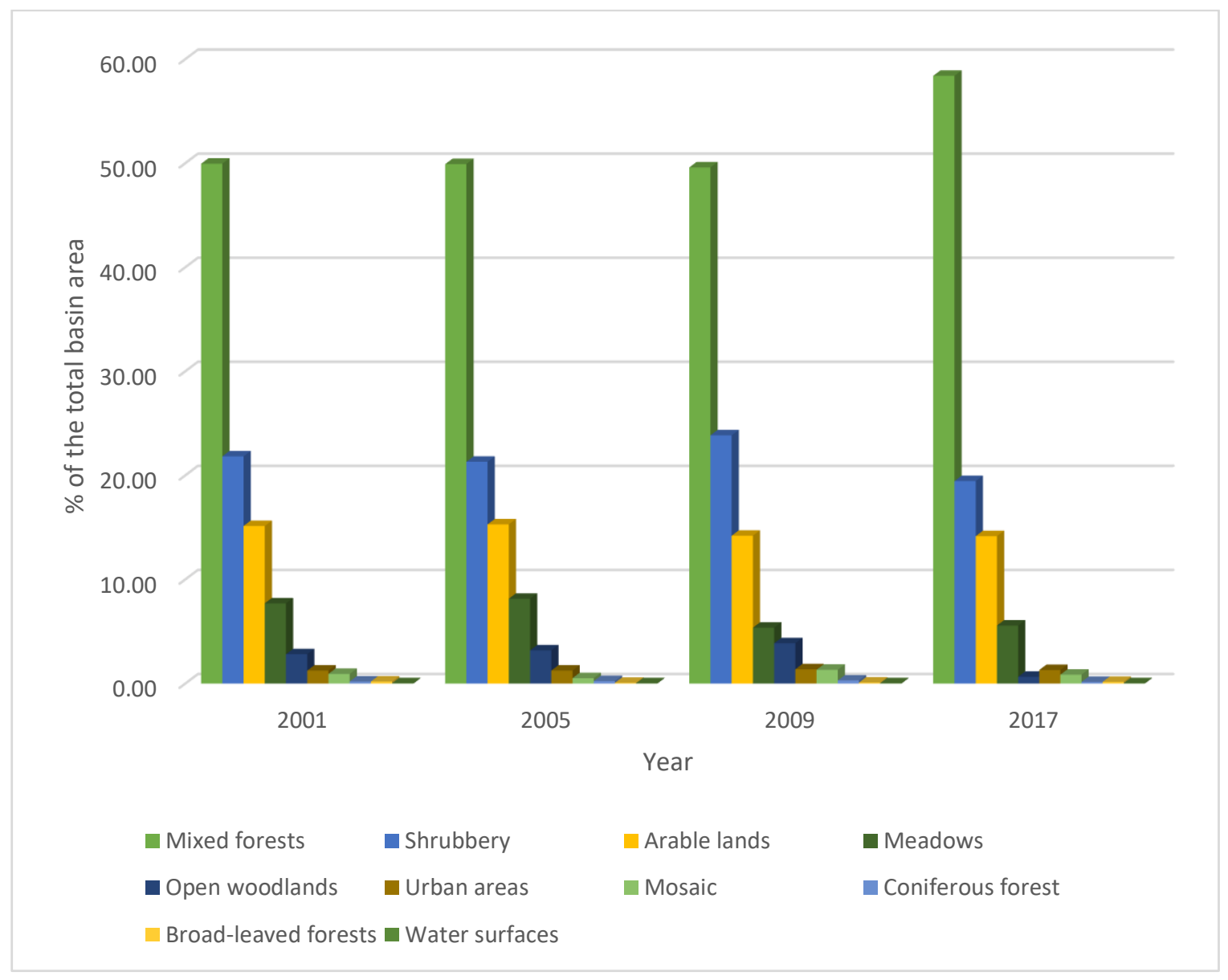

Figure 3. Dynamics of land structure in the Klyazma River basin according to MODIS (\%)

\subsection{Dynamics of Land Use in the Landscape Provinces}

The catchment area of the Klyazma River has a complex landscape structure. To make a detailed analysis of the main trends in the different parts of the basin, we took remote data from Trends.Earth with $300 \mathrm{~m}$ spatial resolution for six types of lands.

It was found that the trend was towards the sprawl of forest vegetation and the reduction of ploughlands and pastures in the entire basin. The only exception was the interfluve with the Lukh River, where a transition of forest lands into bogs could be observed. The selected sites featured the changes in the land use structure of the landscape provinces (Table 1, Fig. 4).

The land use structure in the Meshchera Province was the most stable: almost $90 \%$ of the province was occupied by forests and their area changed insignificantly.

The revegetation of ploughlands with gray wood soils and soddy podzols had different dynamics. For example, the Klin-Dmitrov Province has both types of soils. Forests most actively overgrew the pastures and ploughlands with soddy cryptopodzols and mesopodzols, which could be observed on Site 1 (the Klin-Dmitrov Ridge). Here, the revegetation rate was the highest (-3.5\%) in the Klyazma River basin. The gray wood soils, represented on the Vladimir High Plain, are the most fertile and agriculturally developed, hence they got overgrown significantly less (Site 2). The Vladimir High Plain has the vastest ploughed-up lands that are actively used in farming. 
The land use dynamics was determined as the difference of electronic raster layers for years 2001-2015. The obtained difference raster was superposed on boundaries of the landscape provinces and the sites, to make a comparative cartographic analysis of the dynamics of land use structure in the Klyazma River basin.

Table 1. Dynamics of land use on the sites

\begin{tabular}{|c|c|c|c|c|c|c|c|c|}
\hline \multirow{2}{*}{ Province } & \multirow{2}{*}{ Site } & \multirow{2}{*}{ Year } & \multicolumn{6}{|c|}{ Land use structure (\%) } \\
\hline & & & Forests & Pastures & Ploughlands & Bogs & Other & Water \\
\hline \multirow{6}{*}{$\begin{array}{l}\text { Klin- } \\
\text { Dmitrov }\end{array}$} & \multirow{2}{*}{1 - Klin-Dmitrov Ridge } & 2001 & 55.9 & 4.1 & 38.5 & 0.0 & 1.6 & 0.0 \\
\hline & & 2015 & 62.0 & 0.8 & 35.0 & 0.0 & 2.2 & 0.0 \\
\hline & Dynamics & & 6.1 & -3.3 & -3.5 & 0.0 & 0.6 & 0.0 \\
\hline & \multirow{2}{*}{2 - Vladimir High Plain } & 2001 & 31.4 & 2.0 & 65.3 & 0.0 & 0.6 & 0.6 \\
\hline & & 2015 & 33.7 & 0.8 & 63.7 & 0.0 & 1.2 & 0.6 \\
\hline & Dynamics & & 2.3 & -1.2 & -1.6 & $\mathbf{0 . 0}$ & 0.6 & 0.0 \\
\hline \multirow{4}{*}{ Meshchera } & \multirow{2}{*}{3 - Meshchera Site } & 2001 & 88.8 & 3.2 & 6.9 & 0.1 & 0.6 & 0.4 \\
\hline & & 2015 & 89.7 & 2.7 & 6.2 & 0.1 & 1.0 & 0.4 \\
\hline & Dynamics & & 0.9 & -0.5 & -0.7 & 0.0 & 0.4 & 0.0 \\
\hline & 4 - Nerl-Klyazma & 2001 & 71.5 & 5.4 & 22.5 & 0.0 & 0.4 & 0.2 \\
\hline \multirow{5}{*}{$\begin{array}{l}\text { Volga- } \\
\text { Klyazma }\end{array}$} & Lowland & 2015 & 76.9 & 1.6 & 20.6 & 0.0 & 0.6 & 0.2 \\
\hline & Dynamics & & 5.4 & -3.8 & -1.9 & 0.0 & 0.2 & 0.0 \\
\hline & \multirow{2}{*}{5 - Lower Lukh Site } & 2001 & 85.4 & 0.1 & 0.8 & 12.5 & 0.0 & 1.2 \\
\hline & & 2015 & 67.0 & 0.1 & 1.1 & 30.6 & 0.0 & 1.2 \\
\hline & Dynamics & & -18.4 & 0.0 & 0.3 & 18.1 & 0.0 & 0.0 \\
\hline \multirow{9}{*}{ Oka-Tsna } & \multirow{2}{*}{ 6-Oka-Tsna Wall } & 2001 & 86.9 & 1.6 & 11.4 & 0.0 & 0.0 & 0.1 \\
\hline & & 2015 & 89.3 & 0.3 & 10.2 & 0.0 & 0.0 & 0.1 \\
\hline & Dynamics & & 2.4 & -1.3 & -1.2 & 0.0 & 0.0 & 0.0 \\
\hline & 7 - Kovrov-Kasimov & 2001 & 76.4 & 2.8 & 20.3 & 0.0 & 0.2 & 0.2 \\
\hline & Plateau & 2015 & 81.1 & 0.2 & 18.0 & 0.0 & 0.4 & 0.2 \\
\hline & Dynamics & & 4.7 & -2.6 & 2.3 & 0.0 & 0.2 & 0.0 \\
\hline & 8 - Gorokhovets Snur & 2001 & 54.3 & 5.8 & 38.2 & 0.2 & 0.4 & 1.0 \\
\hline & Goroknovets spur & 2015 & 59.8 & 2.3 & 35.8 & 0.2 & 0.9 & 1.0 \\
\hline & Dynamics & & 5.5 & -3.5 & -2.4 & 0.0 & 0.5 & $\mathbf{0 . 0}$ \\
\hline \multirow{3}{*}{$\begin{array}{l}\text { Total } \\
\text { Basin }\end{array}$} & & 2001 & 60.5 & 4.9 & 32.1 & 0.4 & 1.4 & 0.7 \\
\hline & & 2015 & 63.7 & 2.3 & 30.4 & 0.8 & 2.1 & 0.7 \\
\hline & Dynamics & & 3.2 & -2.5 & -1.7 & 0.5 & 0.6 & 0.0 \\
\hline
\end{tabular}

The cartographic analysis revealed areas where various lands transitioned from one category to another; refer to Fig. 4. Such transitions mainly occurred due to revegetation of agricultural land with shrubs and grasses. There was also a significant enlargement of waterlogged areas and bogs in the eastern part of the basin: in the Volga-Klyazma Province (interfluve of the rivers Lukh and Klyazma, Site 5) and in the OkaTsna Province (near the Gorokhovets Spur, Site 8). 


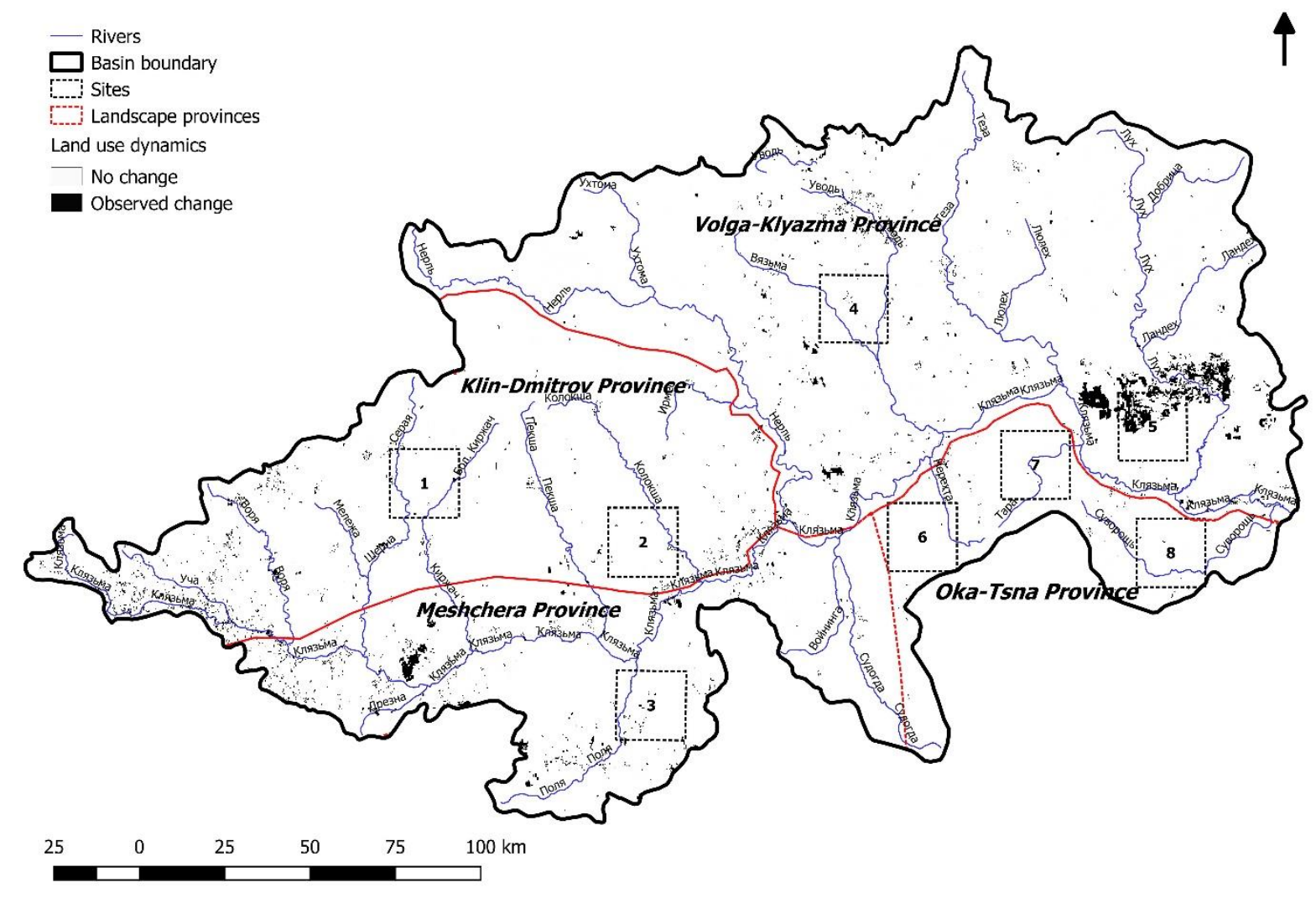

Figure 4. Land use dynamics in the Klyazma River basin in 2001-2015

\subsection{Productivity of Vegetation Cover}

To quantify the productivity of the vegetation cover in the catchment area, the GPP, NPP and RE values were determined in $\mathrm{gC} / \mathrm{cm} 2$ at the height of vegetation season (mid-July) in 2000-2015 based on the MODIS data.

On average, GPP was $59.1 \mathrm{gC} / \mathrm{cm} 2$ and NPP was $39.5 \mathrm{gC} / \mathrm{cm} 2$ for the studied period at the height of the vegetation season in the entire basin of the Klyazma River. GPP was unevenly distributed across the basin (Table 3). Fertile gray wood soils of the Vladimir High Plain do not have high gross productivity, and on that site was even slightly lower than the average, due to the predominance of agrocenoses there. The most productive in the basin were the natural areas of the Oka-Tsna Province. The Gorokhovets Spur has the highest GPP that was higher than the average for the Klyazma River basin. In this area, in comparison with others, there are more grasses and shrubbery that are more productive than forests. Phytoproductivity of the other landscapes corresponded to the average values in the basin.

The productivity indicators varied significantly over the years both generally in the basin and separately by the sites. The coefficient of variation characterizing the sample was rather substantial (Fig. 5, Table 3). 


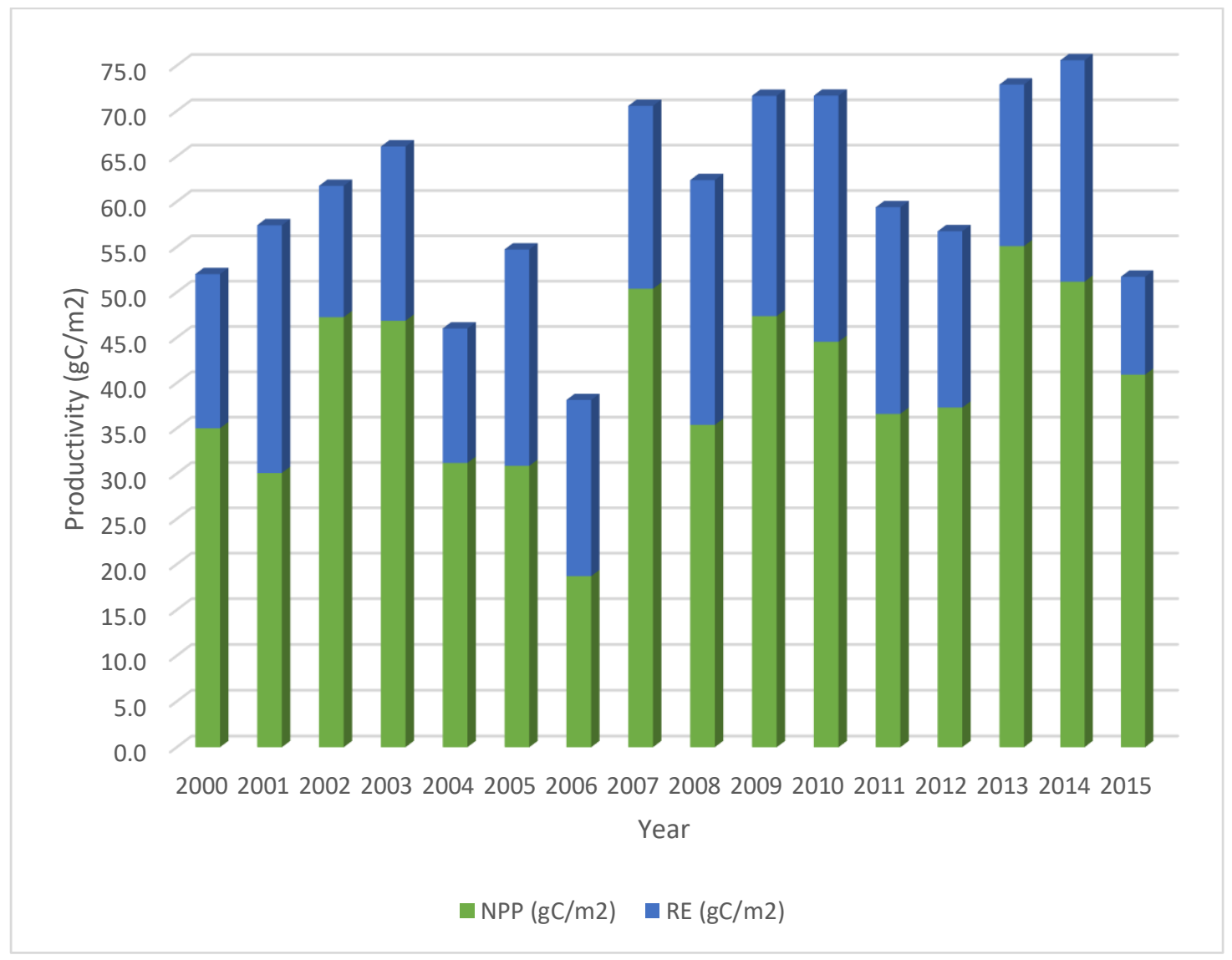

Figure 5. Long-term productivity dynamics in the Klyazma River basin: blue stands for NPP, red stands for RE, and the whole column stands for GPP

\subsection{Carbon Balance in Soil Cover}

The data in Table 2 indicates the change in carbon content in the soil in 2001-2015. In general, the Klyazma River basin ecosystem increased carbon reserves by $0.6 \%$, but the data on the sites showed that the rate and the direction of this process varied in the different landscape provinces of the studied catchment area.

Table 2. Balance of organic carbon in the soil.

\begin{tabular}{ccccc}
\hline Landscape province & Site & Area $\left(\mathrm{km}^{2}\right)$ & $\begin{array}{c}\text { Balance } \\
\left(\mathrm{Cton} / \mathrm{km}^{2}\right)\end{array}$ & $\mathrm{C}(\Delta \%)$ \\
\hline \multirow{2}{*}{ Klin-Dmitrov } & 1- Klin-Dmitrol Ridge & 420 & 96.2 & growth +0.7 \\
Meshchera & 2- Vladimir High Plain & 405 & 7.4 & growth +0.1 \\
& 3- Meshchera Site & 410 & -24.1 & $\begin{array}{l}\text { loss } \\
\text { Volga-Klyazma }\end{array}$ \\
& 4- Nerl-Klyazma Lowland & 410 & 125.9 & growth +0.9 \\
& 5- Lower Lukh Site & 368 & 73.9 & growth +0.3
\end{tabular}




\begin{tabular}{|c|c|c|c|c|}
\hline \multirow{3}{*}{ Oka-Tsna } & 6 - Oka-Tsna Wall & 381 & 119.3 & growth +0.7 \\
\hline & $\begin{array}{c}7 \text { - Kovrov-kasimov } \\
\text { Plateau }\end{array}$ & 402 & 125.2 & growth +0.9 \\
\hline & 8 - Gorokhovets Spur & 257 & 253.5 & growth +1.5 \\
\hline \multicolumn{2}{|c|}{ Klyazma River basin } & 42500 & 92.8 & growth +0.6 \\
\hline
\end{tabular}

\section{DISCUSSION}

\subsection{Analysis of Productivity Dynamics in the River Basin}

From 2000 to 2015, the GPP, NPP and RE values in the ecosystem of the Klyazma River basin were fluctuating both up and down as compared to the respective average values. No sustainable trend indicating either growth or decline in productivity was observed. The value distribution histograms showed periods of growth, decline and steady state of productivity, which can be mainly associated with the weather conditions.

Both GPP and NPP were stable in 2007-2010 when the gross productivity remained in the range from 70 to $71 \mathrm{gC} / \mathrm{m} 2$ and the net productivity was $44 \mathrm{gC} / \mathrm{m} 2$ in average. Despite the hot and arid summer of 2010 when the average temperature in July reached $24.8{ }^{\circ} \mathrm{C}$, the total precipitation in June and July was $54 \mathrm{~mm}$, the number of days with weather elements was only 22 , and the relative humidity was under $60 \%$ (Raspisaniye Pogody, 2019). The considered indicators remained at a relatively high level: GPP was 71 $\mathrm{gC} / \mathrm{m} 2$ and NPP was $\mathrm{gC} / \mathrm{m} 2$. On the other hand, the consumption for autotrophic respiration was also substantial: RE was $27 \mathrm{gC} / \mathrm{m} 2$. It could have been caused by adverse weather conditions and large-scale summer fires.

The GPP and NPP maximums occurred during the humid summer of 2014 and reached 75 and $51 \mathrm{gC} / \mathrm{m} 2$, respectively. The average temperature in July 2014 was $19.3{ }^{\circ} \mathrm{C}$, the total precipitation in June and July was $156 \mathrm{~mm}$, the number of days with weather elements was 30, and the relative humidity did not exceed 66\% (Raspisaniye Pogody, 2019).

The worst period for the land cover was year 2006 when GPP dropped to $38 \mathrm{gC} / \mathrm{m} 2$ and NPP was 18 $\mathrm{gC} / \mathrm{m} 2$, the average temperature in July was below normal and reached only $16.6{ }^{\circ} \mathrm{C}$, and the total precipitation in June and July was $77 \mathrm{~mm}$ (Raspisaniye Pogody, 2019). A relatively small amount of precipitation in May and June, amounting to $62 \mathrm{~mm}$, could also have had a negative impact on phytoproductivity. Apparently, this factor contributed to the decrease in groundwater levels by July and formed the conditions of water deficit.

\subsection{Productivity Dynamics in the Landscape Provinces}

We compared the phytoproductivity dynamics of the whole river basin and the landscape provinces represented by the sites (Fig. 6). The periods of increased and decreased productivity in different provinces generally coincided; however, the magnitude of these fluctuations was different.

The most significant changes in the productivity indicators from year to year were observed in the KlinDmitrov Ridge, which can be confirmed by the maximum coefficients of variation for GPP (23.3\%), NPP 
(26.3\%) and RE (33.1\%) (Table 3). The smallest productivity fluctuations occurred in the Oka-Tsna Wall: here they were below the basin average.

The sites were grouped by productivity based on visual analysis and subsequent comparison of the histograms. The sites having similar productivity parameters but confined to different landscapes, generally had a similar distribution of lands. Thus, the Meshchera Site (Site 3) and the Oka-Tsna Wall (Site 6), both covered with mixed forest by $86-88 \%$, were alike in terms of productivity distribution. The landscapes of the Volga-Klyazma Province (Site 4) and the Kovrov-Kasimov Plateau (Site 7), both covered with mixed forest by $71-76 \%$, were alike in terms of productivity distribution and differed from the other sites by the most significant variation of indicators.

The most dynamic site was the interfluve of the rivers Lukh and Klyazma (Site 5) where the structure of land use had taken significant changes. Thus, the forested areas decreased by $18 \%$ due to bogging but the productivity indicators in the studied period were the lowest. On the other hand, the Gorokhovets Spur (Site 8) and the Klin-Dmitrov Ridge (Site 1), both having 50\% of mixed forests and 35-38\% of arable lands, were grouped by the NPP to RE ratio.

The Vladimir High Plain (Site 2) can be isolated as unique in terms of productivity distribution. It bore no similarity to any other site but had the productivity distribution similar to the river basin taken as a whole. This site differs from the others by the degree of cultivation with $60 \%$ of arable lands and $30 \%$ of forests (Fig. 6).

On average, in the Klyazma River basin the coefficient of variation of GPP was $18.5 \%$, while RE fluctuated more significantly, the coefficient of variation being $27.9 \%$. It should be highlighted that the dynamics of landscape productivity on the selected sites, referring to various landscapes, generally agreed with the processes in the whole river basin.

The coefficients of correlation between variables GPP, NPP and RE as a whole for the basin landscapes and the vegetation of these areas were maximum (Table 3). However, the dynamics of plant community productivity on the Vladimir High Plain and the Klin-Dmitrov Ridge most closely agreed with the dynamics of productivity of the whole river basin.

Since these sites and the river basin appear to have matching patterns of phytoproductivity dynamics, they can be used as monitoring sites for the Klyazma River basin. At that, the Klin-Dmitrov Ridge is even more preferable since it is more consistent with the whole river basin in terms of land use. 


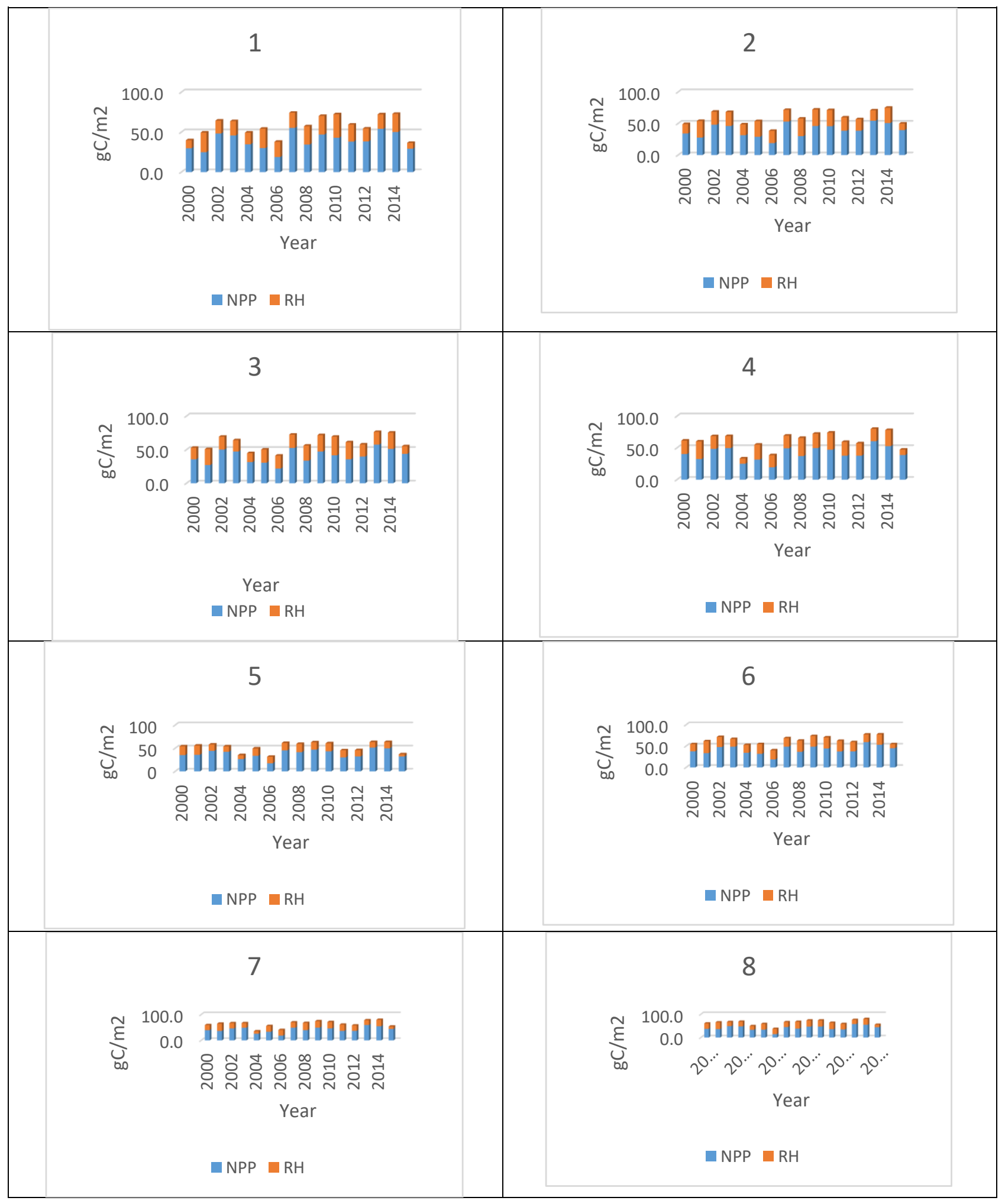

Figure 6. Graphical distribution of GPP, NPP and RE over 15 years in the landscapes of the Klyazma River basin: (1) Klin-Dmitrov Ridge, (2) Vladimir High Plain, (3) Meshchera Site, (4) Nerl-Klyazma Lowland, (5) Lower Lukh Site, (6) Oka-Tsa Wall, (7) Kovrov-Kasimov Plateau, (8) Gorokhovets Spur 
Table 3. Statistical indicators of productivity distribution

\begin{tabular}{|c|c|c|c|c|c|}
\hline \multirow{2}{*}{ Province } & \multirow{2}{*}{ Site } & \multirow{2}{*}{ Indicator } & \multicolumn{3}{|c|}{ Productivity $\left(\mathrm{gC} / \mathrm{m}^{2}\right)$} \\
\hline & & & GPP & NPP & $\mathrm{RE}$ \\
\hline \multirow{6}{*}{ Klin-Dmitrov } & \multirow{3}{*}{$\begin{array}{c}1-\text { Klin-Dmitrov } \\
\text { Ridge }\end{array}$} & $\overline{\mathrm{X}} \pm \sigma$ & $56.5 \pm 13.2$ & $38.4 \pm 10.1$ & $18.0 \pm 6.0$ \\
\hline & & $\mathrm{V}(\%)$ & 23.3 & 26.3 & 33.1 \\
\hline & & $\mathrm{r}$ & 0.92 & 0.93 & 0.94 \\
\hline & \multirow{3}{*}{$\begin{array}{l}2 \text { - Vladimir High } \\
\text { Plain }\end{array}$} & $\overline{\mathrm{x}} \pm \sigma$ & $58.4 \pm 11.4$ & $38.9 \pm 10.5$ & $20.0 \pm 6.0$ \\
\hline & & $\mathrm{V}(\%)$ & 19.5 & 24.3 & 28.5 \\
\hline & & $\mathrm{r}$ & 0.97 & 0.98 & 0.92 \\
\hline \multirow{3}{*}{ Meshchera } & \multirow{3}{*}{3 - Meshchera Site } & $\overline{\mathrm{x}} \pm \sigma$ & $59.6 \pm 11.0$ & $40.2 \pm 9.2$ & $19.0 \pm 5.0$ \\
\hline & & $\mathrm{V}(\%)$ & 18.5 & 22.8 & 26.2 \\
\hline & & $\mathrm{r}$ & 0.94 & 0.97 & 0.91 \\
\hline \multirow{6}{*}{ Volga-Klyazma } & \multirow{3}{*}{$\begin{array}{l}4 \text { - Nerl-Klyazma } \\
\text { Lowland }\end{array}$} & $\overline{\mathrm{x}} \pm \sigma$ & $59.9 \pm 13.3$ & $40.5 \pm 10.0$ & $19.0 \pm 6.0$ \\
\hline & & $\mathrm{V}(\%)$ & 22.2 & 24.7 & 31.8 \\
\hline & & $\mathrm{r}$ & 0.93 & 0.96 & 0.91 \\
\hline & \multirow{3}{*}{5 - Lower Lukh Site } & $\overline{\mathrm{x}} \pm \sigma$ & $50.9 \pm 11.0$ & $37.5 \pm 9.0$ & $13.4 \pm 4.2$ \\
\hline & & $\mathrm{V}(\%)$ & 21.7 & 24.1 & 31.3 \\
\hline & & $\mathrm{r}$ & 0.86 & 0.86 & 0.81 \\
\hline Oka-Tsna & 6 - Oka-Tsna Wall & $\overline{\mathrm{x}} \pm \sigma$ & $61.7 \pm 10.6$ & $41.2 \pm 9.1$ & $20.0 \pm 5.0$ \\
\hline
\end{tabular}

Note: $\overline{\mathrm{x}}$ is the arithmetic mean, $\sigma$ is the standard deviation, $\mathrm{V}(\%)$ is the coefficient of variation, and $\mathrm{r}$ is the coefficient of correlation.

\subsection{Carbon Balance and State of Soil and Vegetation Cover in the Landscape Provinces}

We compared the data on the carbon balance in the soil cover of the Klyazma River basin and the change in land use structure (Table 2). The carbon balance in the soil cover of the whole river basin was positive, with the exception of the Meshchera Site and the Vladimir High Plain where there were insignificant changes over the period from 2000 to 2015 . Therefore, the carbon balance can be assumed to be zero. The Meshchera Site was marked by slightly negative dynamics as the soil carbon content reduced by $0.1 \%$, while the Vladimir High Plain had a $0.1 \%$ increase in soil carbon content.

The land use structure of the sites with the zero balance was notably different. The Meshchera Site is mostly occupied by forests (89\%), and the Vladimir High Plain, by cultivated land (65\%). A common feature of these sites is the stability of land. On the Meshchera Site, the area of forest vegetation changed insignificantly, and on the Vladimir High Plain, forested territories grew only slightly and farmland areas remained almost unchanged.

In the other landscapes, the farmlands were actively overgrown with forest vegetation, and at the same time, the rate of carbon accumulation in the soil increased. For the analyzed period, this accumulation amounted to $0.6 \%$ in the Klyazma River basin. 
On the Klin-Dmitrov Ridge, the rate of carbon deposition in the soil corresponded to the river basin average $(0.7 \%)$, which must be taken into account when choosing key sites for environmental monitoring. The highest rate of carbon accumulation in the soil was observed on the Gorokhovets Spur (1.5\%).

Summing up, in the Klyazma River basin, the overgrowing of agricultural land with forest vegetation was accompanied by increasing carbon accumulation in the soil. In the landscapes with a stable land use structure, the carbon balance was zero or slightly negative.

We compared the data on productivity and long-term dynamics of the vegetation cover to the organic carbon content in the soil for each site:

Site 1. On the Klin-Dmitrov Ridge, the average indicators of productivity dynamics over the studied period were minimum: GPP $=57 \mathrm{gC} / \mathrm{m}^{2}$ and $\mathrm{NPP}=38 \mathrm{gC} / \mathrm{m}^{2}$. However, the correlation between the productivity dynamics on this site and in the whole river basin was rather good. The variation of values was higher in relation to other sites. The carbon content in the soil grew by $0.7 \%$, which is slightly higher than the river basin average. The gain of organic carbon in the soil was confined to $1.6 \%$ of the site.

Site 2. The Vladimir High Plain had average indicators of long-term productivity dynamics: GPP $=58$ $\mathrm{gC} / \mathrm{m}^{2}$ and $\mathrm{NPP}=39 \mathrm{gC} / \mathrm{m}^{2}$. The coefficient of correlation between the productivity dynamics of the entire basin and this site was maximum (0.97). The carbon content in the soil grew by $0.06 \%$, which can be considered akin to neutral balance. However, arable lands lost a large mass of organic carbon in the soil, and only a small number of forests could replenish it, hence the neutral balance was achieved. The increased mass of organic carbon was gained from the smallest area $0.5 \%$ of the site.

Site 3. The Meshchera Site had average indicators of long-term productivity dynamics: $\mathrm{GPP}=60 \mathrm{gC} / \mathrm{m}^{2}$ and NPP $=40 \mathrm{gC} / \mathrm{m}^{2}$. The productivity was steady and varied insignificantly. The carbon content decreased by $0.1 \%$ due to the growth of artificial surfaces and bogs. The carbon balance was akin to zero.

Site 4. On the Nerl-Klyazma Lowland, the average indicators of productivity dynamics over the studied period were moderate: $\mathrm{GPP}=60 \mathrm{gC} / \mathrm{m}^{2}$ and NPP $=41 \mathrm{gC} / \mathrm{m}^{2}$. A relatively high increase in the organic carbon content $(0.9 \%)$ was due to the high positive dynamics of mixed forest growth (by $5 \%$ ).

Site 5. The Lower Lukh Site had average indicators of long-term productivity dynamics: GPP $=51 \mathrm{gC} / \mathrm{m}^{2}$ and NPP $=37 \mathrm{gC} / \mathrm{m}^{2}$. However, there was a small positive increase in the organic carbon content $(0.3 \%)$, apparently, due to the fact that the area of wetlands grew by $18 \%$ over 15 years. The carbon content increase can, possibly, be associated with the deposition of carbon in plant residues as a result of waterlogging processes in the bogs.

Sites 6 and 7. The Kovrov-Kasimov Plateau and the Oka-Tsna Wall had high GPP amounting to $62 \mathrm{gC} / \mathrm{m}^{2}$ while NPP was moderate and remained $41 \mathrm{gC} / \mathrm{m}^{2}$. A relatively high increase in the organic carbon content $(0.7-0.8 \%)$ was observed on $1-2 \%$ of these sites.

Site 8. The Gorokhovets Spur had maximum GPP that reached $63 \mathrm{gC} / \mathrm{m}^{2}$ while NPP was still $41 \mathrm{gC} / \mathrm{m}^{2}$. The organic carbon content grew significantly by $1.5 \%$, which points to plant litter accumulation on a considerable territory (up to $6 \%$ of the site area) where the succession processes take place.

Due to the reduction in the area of arable land and pastures (alienation for urban development and waterlogging), the mass of organic carbon in the soil decreased. This is especially evident in the Meshchera Province that showed a negative trend of organic carbon accumulation in the soil.

In whole, in the Klyazma River basin ecosystem, GPP was $\mathrm{gC} / \mathrm{m}^{2}$, NPP was about $40 \mathrm{gC} / \mathrm{m}^{2}$, and the carbon content in the soil grew by $0.6 \%$.

\subsection{Recommendation for Environmental Monitoring}


The analysis of productivity, land use and carbon accumulation in the soil in the whole Klyazma River basin and the sites pointed to the Klin-Dmitrov Ridge as a representative site for environmental monitoring in the studied catchment area. It matches to the whole river basin by several parameters (productivity and its dynamics, land use structure, carbon accumulation), and hence Site 1 can serve as a model of the Klyazma River basin.

It should be noted that although the catchment area of the Klyazma River is rather large, it functions stably enough in the regime of a holistic ecosystem. This is facilitated by a favorable correlation of climatic parameters, the location of various land areas, and a relatively stable anthropogenic load.

\section{CONCLUSIONS}

The territory of the Klyazma River basin features a complex combination of different landscape structures, i.e. the landscape provinces. Each of them is marked by a diverse composition of geomorphological and soil-vegetation features. Moreover, the biological processes that characterize the organic matter dynamics in the form of plant production, the accumulation of organic matter, etc. can be distinguished by both rate and intensity.

The landscapes react differently to changes in climatic parameters and land use. Thus, the active revegetation of farmland by forests gives the increased rate of carbon accumulation in the soil. The landscapes covered with grasses and shrubs are more productive than those covered with forest. On the other hand, woody biotopes are more stable in their development over time.

Although in 2000-2015 there were fluctuations of GPP, NPP and RE in the ecosystem of the Klyazma River basin and the said indicators could have been both above and below average, no stable trend toward either increase or decrease in productivity can be noted.

The overgrowing of ploughlands and pastures with forest is accompanied by an increase in carbon deposition in the soil. For the whole basin, the increase in carbon content was $0.6 \%$ over the fifteen-year period from 2000 to 2015 . On the sites with a stable land use structure, the carbon balance was akin to zero (the Vladimir High Plain) or slightly negative (the Meshchera Site).

It can be confirmed that large natural ecosystems such as river catchment areas marked by a strict territorial certainty of the material and energy flow distribution, have a set of compensation mechanisms to maintain relative functioning stability. The smaller structures that make up the basin in the form of different landscapes react more dynamically to various impacts of both natural and anthropogenic character. This must be taken into account when assessing the ecosystem resilience to changing external conditions

\section{REFERENCES}

Bazilevich, N. I., Grebenshchikov, O. S. \& A. A. Tishkov. (1986). Geograficheskiye zakonomernosti struktury $i$ funktsionirovaniya ekosistem [Geographic Patterns of the Structure and Functioning of Ecosystems]. Moscow: Nauka. (in Russian)

Chen, Y., Shen, W., Gao, S., Zhang, K., Wang, J. \& Huang, N. (2019). Estimating Deciduous Broadleaf Forest Gross Primary Productivity by Remote Sensing Data Using a Random Forest Regression Model. Journal of Applied Remote Sensing, 13 (3), 38502. doi: 10.1117/1.JRS.13.038502

Dedeoglu, M., L., Basayigit, L., Yuksel, M, \& Kaya, F. (2019). Assessment of the Vegetation Indices on Sentinel-2A Images for Predicting the Soil Productivity Potential in Bursa, Turkey. Environmental Monitoring and Assessment, 
192 (1), 16. doi: 10.1007/s10661-019-7989-8.

Deng, L., Zhu, G., Tang, Z. \& Shangguan, Z.P. (2016). Global Patterns of the Effects of Land-Use Changes On Soil Carbon Stocks. Global Ecology and Conservation, 5, 127-138. doi: 10.1016/j.gecco.2015.12.004

Deng, L., Liu, G.-B., \& Z.-P. Shangguan. (2014). Land Use Conversion and Changing Soil Carbon Stocks in China's ‘Grain-for-Green' Program: A Synthesis. Global Change Biology 20 (11). 3544-3556. doi: 10.1111/gcb.12508

Dong, J., Metternicht, G., Hostert, P., Fensholt, R., \& Chowdhury, R. R. (2019). Remote Sensing and Geospatial Technologies in Support of a Normative Land System Science: Status and Prospects. Current Opinion in Environmental Sustainability, 38, 44-52. doi: 10.1016/j.cosust.2019.05.003

Ermolayev, O. P., Maltsev, K. A. \& Ivanov, M. A. (2014). Avtomatizirovannoye postroyeniye granits basseynovykh geosistem dlya Privolzhskogo federalnogo okruga [Automated Construction of the Basin Geosystem Boundaries for the Volga Federal District]. Geografiya i prirodnyye resursy = Geography and Natural Resources, 3, 33-39 (in Russian)

Fitoka, E., Tompoulidou, M., Hatziiordanou, L., Apostolakis, A., Hofer, R. , Weise, K., \& Ververis, C. (2020). Water-Related Ecosystems' Mapping and Assessment Based on Remote Sensing Techniques and Geospatial Analysis: The SWOS National Service Case of the Greek Ramsar Sites and Their Catchments. Remote Sensing of Environment, 245, 111795. doi: .org/10.1016/j.rse.2020.111795

Friedl, M., \& D. Sulla-Menashe. (2015). MCD12C1 MODIS/Terra+Aqua Land Cover Type Yearly L3 Global 0.05Deg CMG V006. doi: 10.5067/MODIS/MCD12C1.006. Accessed 6 Sept 2019.

Goetz, S. J., \& Prince, S. D. (1999). Modelling Terrestrial Carbon Exchange and Storage: Evidence and Implications of Functional Convergence in Light-use Efficiency. Global Change Biology, 28, 57-92. doi: 10.1016/S00652504(08)60029-X

Guo, L. B., \& Gifford, R.M. (2002). Soil Carbon Stocks and Land Use Change: A Meta-Analysis. Global Change Biology, 345-360.

Hashimoto, H., Wang, W., Milesi, C., White, M. A., Ganguly, S., Gamo, M., Hirata, R. et al. (2012). Exploring Simple Algorithms for Estimating Gross Primary Production in Forested Areas from Satellite Data. Remote Sensing, 4, 303-326. doi: 10.3390/rs4010303

Isachenko, A. G. (1991). Landshaftovedeniye i fiziko-geograficheskoye rayonirovaniye [Landscape Science and Physical-Geographical Zoning]. Moscow: Vysshaya shkola. (in Russian)

Krasilnikov, P. V. (2015). Stable Carbon Compounds in Soils: Their Origin and Functions. Eurasian Soil Science, 48: 997-1008. doi: 10.1134/S1064229315090069

Kudeyarov, V. N., Zavarzin, G. A., Blagodatskiy, S. A., Borisov, A. V.,Voronin, P. Y., Demkin, V. A., Demkina, T. S., et al. (2007). Puly i potoki ugleroda v nazemnykh ekosistemakh Rossii [Carbon Pools and Flows in Terrestrial Ecosystems of Russia]. Moscow: Nauka. (in Russian)

Li, X., Du, H., Mao, F., Zhou, G., Han, N., Xu, X., Liu, Y., et al. (2019). Assimilating Spatiotemporal MODIS LAI Data with a Particle Filter Algorithm for Improving Carbon Cycle Simulations for Bamboo Forest Ecosystems. Science of The Total Environment, 694, 133803. doi: 10.1016/j.scitotenv.2019.133803

Meyer, D., \& Riechert, M. (2019). Open Source QGIS Toolkit for the Advanced Research WRF Modelling System. Environmental Modelling and Software, 112, 166-178. doi: 10.1016/j.envsoft.2018.10.018

Novick, K. A., Oishi, A. C., Ward, E. J., Siqueira, M. B. S., Juang, J. Y., \& Stoy, P. C. (2015). On the Difference in the Net Ecosystem Exchange of CO2 Between Deciduous and Evergreen Forests in the South-Eastern United States. Global Change Biology, 2, 827-842. 
Odum, E. P. (1983). Basic Ecology. Philadelphia, PA: Saunders.

Ovington, J. D. (1962). Quantitative Ecology and the Woodland Ecosystem Concept. Advances in Ecological Research, 1, 103-192. doi: 10.1016/S0065-2504(08)60302-5

Prince, S. D. (2019). Challenges for remote sensing of the Sustainable Development Goal SDG 15.3.1 Productivity Indicator. Remote Sensing of Environment, 234, 1-7.

Qader, S. H., Atkinson, P. M., \& Dash, J. (2015). Spatiotemporal Variation in the Terrestrial Vegetation Phenology of Iraq and Its Relation with Elevation. International Journal of Applied Earth Observation and Geoinformation, 41, $107-117$.

Raspisaniye Pogody LLC. 2019. Weather Forecasts. https://rp5.ru/ Accessed 23 September 2019.

Robinson, N. P., Allred, B. W., Smith, W. K., Jones, M. O., Moreno, A., Erickson, T. A., Naugle, D. E., \& Running, S. W. (2018). Terrestrial Primary Production for the Conterminous United States Derived from Landsat $30 \mathrm{~m}$ and MODIS 250 m. Remote Sensing in Ecology and Conservation, 4 (3), 264-280.

Running, S., Mu, Q.,\& Zhao, M. (2015). MOD17A2H MODIS/Terra Gross Primary Productivity 8-Day L4 Global 500m SIN Grid V006. doi: 10.5067/MODIS/MOD17A2H.006. Access. 3 Sept 2019.

Salunkhe, O., Khare, P. K., Kumari, R., \& Khan, M. L. (2018). A Systematic Review on the Aboveground Biomass and Carbon Stocks of Indian Forest Ecosystems. Ecological Processes, 7, 17. doi: 10.1186/s13717-018-0130-z

SoilGrids: Global Gridded Soil Information. Soil Project. http://soilgrids.org Access. 2 Sept 2019.

Sun, B., Li, Z., Gao, W., Zhang, Y., Gao, Z., Song, Z., Qin, P., \& Tian, X. (2019). Identification and Assessment of the Factors Driving Vegetation Degradation/ Regeneration in Drylands Using Synthetic High Spatiotemporal Remote Sensing Data-A case Study in Zhenglanqi, Inner Mongolia, China. Ecological Indicators, 107, 1-16. doi: 10.1016/j.ecolind.2019.105614

Tian, H., Cao, C., Chen, W., Bao, S., Yang, B., \& Myneni, R. B. (2015). Response of Vegetation Activity Dynamic to Climatic Change and Ecological Restoration Programs in Inner Mongolia from 2000 to 2012. Ecological Engineering, 82, 276-289.

Trends.Earth. 2018. Conservation International. http://trends.earth. Access. 2 Sept 2019.

Trifonova, T. A. (Ed.) (2018). Ekologicheskiy atlas basseyna reki Klyazma. Chelovek v okruzhayushchey srede [Ecological Atlas of the Klyazma River Basin. Man in the Environment]. Vladimir: Stoletov Vladimir State University (in Russian)

Trifonova, T. A. (2005). Razvitiye basseynovogo podkhoda v pochvennykh i ekologicheskikh issledovaniyakh [Development of a Basin Approach in Pedological and Environmental Studies]. Eurasian Soil Science, 38 (9), 931937.

Trifonova, T. A. (2008). Rechnoy vodosbornyy basseyn kak samoorganizuyushchayasya prirodnaya geosistema [River Catchment Basin as a Self-Organizing Natural Geosystem]. Izvestiya Rossiiskoi Akademii Nauk. Seriya Geograficheskaya = Bulletin of the Russian Academy of Sciences. Geography Series, 1, 28-36. (in Russian)

Trifonova, T. A., \& Mishchenko, N. V. (2018). Osobennosti sostoyaniya pochvenno-rastitelnogo pokrova basseyna r. Klyazmy s ispolzovaniyem dannykh distantsionnogo zondirovaniya [Assessment of Soil and Vegetation Cover of the Klyazma River Basin Using Remote Sensing Data]. In T. A. Trifonova (Ed.), Ecology of River Basins: Proceedings of the 9th International Scientific and Practical Conference (vol. 1, pp. 311-316). Vladimir: Stoletov Vladimir State University. (in Russian) 
Truchy, A., D., Angeler, G., Sponseller, R. A., Johnson, R. K., \& McKie, B. G. (2015). Chapter Two - Linking Biodiversity, Ecosystem Functioning and Services, and Ecological Resilience: Towards an Integrative Framework for Improved Management. Advances in Ecological Research, 53, 55-96. doi: 10.1016/bs.aecr.2015.09.004

Turner, D. P., Rifts, W. D., Cohen, W. B., Gower, S. T., Running, S. W., Zhao, M., Costa, M. H., Ahl, D. E. (2006). Evaluation of MODIS NPP and GPP Products Across Multiple Biomes. Remote Sensing of Environment, 102, 282 292. doi: 10.10161j.rse.2006.02.017

Valentini, R., Matteucci, G., Dolman, A. J., Schulze, E. D., Rebmann, C., Moors, E. J., Granier, A., et al. (2000). Respiration as the Main Determinant of Carbon Balance in European Forests. Nature, 40, 861-865.

Van der Werf, G.R., Morton, D. C., DeFries, R. S., Olivier, J. G., Kasibhatla, P. S., Jackson, R. B., Collatz, G. J., \& Randerson, J. T., (2009). CO2 Emissions from Forest Loss. Nature Geoscience, 2, 737-738.

Varghese, R., \& Behera, M. D. (2019). Annual and Seasonal Variations in Gross Primary Productivity Across the Agro-Climatic Regions in India. Environmental Monitoring and Assessment, 191(4), 1-19.

Wang, Z., Wang, Z., Zhang, B., Lu, C., \& Lu, R. (2015). Impact of Land Use/Land Cover Changes on Ecosystem Services in the Nenjiang River Basin, Northeast China. Ecological Processes, 4, 11. doi: 10.1186/s13717-015-0036y

Wu, C., Niu, Z., \& Gao, S. (2010). Gross Primary Production Estimation from MODIS Data with Vegetation Index and Photosynthetically Active Radiation in Maize. Journal of Geophysical Research, 115, D1212.

Zhang, M., \& Zeng Y., (2018). Fusion of High Spatial and Temporal Resolution Data to Estimate Vegetation Net Primary Productivity. Journal of Remote Sensing, 22, (1): 143-152. 